\title{
Assessment of Soil Contamination by Heavy Metals: A Case of Turkistan Region
}

\author{
Aktore Zhanibekov $^{1 *}$, Raziya Issayeva ${ }^{1}$, Sergey Golovatyi ${ }^{2}$, Aibala Taspoltayeva ${ }^{3}$, \\ Akbota Aitimbetova ${ }^{1}$, Arailym Nurtayeva ${ }^{1}$, Zhangeldi Kurganbekov ${ }^{1}$, \\ Aigerim Tulbasiyeva ${ }^{1}$ \\ ${ }^{1}$ Department of Ecology, South Kazakhstan University named after M. Auezov, Shymkent, Kazakhstan \\ ${ }^{2}$ Department of Ecological Monitoring and Management, Belarusian State University, Minsk, Belarus \\ ${ }^{3}$ Department of Food Technology and Safety, South Kazakhstan University named after M. Auezov, \\ Shymkent, Kazakhstan
}

Received: 14 July 2021

Accepted: 27 September 2021

\begin{abstract}
The ecological situation continues to remain very tense in the Turkistan region, which is associated with the consequences of the extensive economic activity of the past decades with the use of outdated technologies, as well as the urbanization of the city of Shymkent. The aim: to determine the impact of industrial pollution on the state of soils in technogenic landscapes. Objectives: (1) to identify polluted industrial areas in the Turkistan region; (2) to distinguish the primary pollutants emitted from industries in the Turkistan region; and (3) to assess the state of soil in industrial areas of the Turkistan region. To obtain a qualitative analysis of the soil, the method of atomic absorption spectrometry was used, then the method of a scanning electron microscope was used to obtain enlarged images and morphology of the soil. The scanning electron microscope made it possible to obtain quantitative data on the elements contained in soils. The examined soil specimens were found to have very low concentrations of metals, such as aluminum (Al), silicon ( $\mathrm{Si}$ ), phosphorus (P), sulfur (S), and titanium (Ti). The primary pollutants $(\mathrm{Pb}, \mathrm{Zn}, \mathrm{Cu}$, and $\mathrm{Cd})$ were determined. These metals were present in concentrations that significantly exceeded the regional background values.
\end{abstract}

Keywords: heavy metal pollution, soil, soil contamination, urban

\section{Introduction}

Heavy metals are already the second most hazardous substances, yielding to pesticides and significantly ahead of such well-known pollutants as carbon dioxide and sulfur. Heavy metal contamination is associated

e-mail: zhanibekovakk@rambler.ru with their widespread use in industrial production [1]. In connection with imperfect cleaning systems, heavy metals enter the environment, including the soil, polluting and poisoning it. Heavy metals are special pollutants that must be monitored in all environments because they can persist for a long time as a result of poor disposal in landfills and industrial waste, which is especially relevant for the republics of the former Soviet Union [2]. 
Many heavy metals have high biological activity and are able to accumulate in natural environments, including the human body. This accumulation takes place and at concentrations much lower than the maximum permissible, especially in children. The greatest danger to humans and the environment is from mercury and lead [3]. They are alien to bioorganisms in any content and therefore are included in the list of the main pollutants (global eco-toxicants) by a number of international organizations [4, 5]. Essential elements such as $\mathrm{Zn}$ and $\mathrm{C}$ can also exhibit toxic effects at elevated concentrations.

Among the pollutants, the hazardous heavy metals such as arsenic (As), cadmium $(\mathrm{Cd})$, lead $(\mathrm{Pb})$, copper $(\mathrm{Cu})$, chromium $(\mathrm{Cr})$, nickel $(\mathrm{Ni})$, zinc $(\mathrm{Zn})$, aluminum (Al), and manganese $(\mathrm{Mn})$ have known to be the major threats to the environment [6-8] and human health [8$10]$.

First of all, heavy metals change the biological activity of the soil. Microscopic fungi, ammonifiers, nitrogen-fixing bacteria, and enzymes that control the catalase, invertase, and cellulose activity of the soil were found the most sensitive. The general indicator of soil life or biological activity is soil respiration. When soil is mildly polluted (plants continue to grow), heavy metals, primarily $\mathrm{Cr}$, stimulate the microbiological activity and enhance soil respiration (the production of carbon dioxide). Consequently, soil loses humus. In addition, chromium depreciates the catalase activity of the dark-colored soil, rich in humus [1, 11-16].

Today, the massive increase in industrial production is accompanied by the release of high loads of heavy metals into the environment. A substantial portion of these contaminants spread around the pollution source, resulting in the emergence of geochemical human-induced perturbations across a landscape. Other portion of chemical elements is carried away from the pollution source by natural forces, which leads to the contamination of new areas.

The major anthropogenic sources of soil pollution by heavy metals are thermal power stations, transport, and chemical controls used in agriculture. Plants grown in contaminated soils accumulate an excessive amount of heavy metals beyond the maximum permissible level (MPL). Metals such as zinc, lead, and cadmium are more readily taken up by plants when compared to other micronutrients; therefore, the risks of absorbing a hazardous concentration of these metals is higher [17].

Most studies determine the contents of heavy metals and other chemical elements in soil using physical methods and atomic absorption spectrometry [2, 1820]. One of the indicators of soil environmental quality is the presence of essential micronutrients under the maximum permissible level (MPL). According to soil quality assessments [21-24], some metals $(\mathrm{Cd}, \mathrm{Pb}, \mathrm{Cu}$, $\mathrm{Zn}$, and $\mathrm{Cr}$ ) found around large industrial enterprises and along highway corridors in urban areas exceed their MPLs.
The problem of intoxication with heavy metals is very relevant for the territory of the Turkistan region, where there are large sources of pollution: chemical plants and enterprises. Therefore, it is extremely important to control the content of $\mathrm{Hg}$ and other heavy metals in the environment. There are no comprehensive studies on the distribution of heavy metals in soils in this region, which determined the relevance of this study, the nearest region is Armenia [22]. The aim of the study was to investigate the peculiarities of heavy metals accumulation in soils of Turkestan on the example of Turkestan region and Shimkent city. To obtain the necessary information, a comprehensive approach was used - a combination of standard techniques for determining the concentration of heavy metals [25-32] and methods of atomic sorption spectrometry, as well as the method of obtaining images using a scanning electron microscope.

The objectives of the study were to: (1) determine the contents of heavy metals in soils from some parts of the Turkistan region and the city of Shymkent; (2) identify the natural or anthropogenic sources of heavy metal contaminants through principal component analysis; and (3) determine the levels of heavy metal contamination of topsoils through scanning electron microscopy (SEM) tests. The results of the study may be relevant to urban planners and environmental risk managers seeking to promote responsible, environmentally friendly strategies for economic development.

\section{Material and Methods}

\section{Location and Object of Study}

All studies were carried out on soil samples from the Turkistan region (latitude $43^{\circ} 00^{\prime} \mathrm{N}$, longitude $\left.68^{\circ} 30^{\prime} \mathrm{E}\right)$ and Shymkent $42^{\circ} 18^{\prime} \mathrm{N}$ w. $69^{\circ} 36^{\prime} \mathrm{E} \mathrm{d}$. The total land area of the region is $116.280 \mathrm{~km}^{2}, 4.3 \%$ of the country's territory. The straight-line distance between the most northern and southern points of the region is $600 \mathrm{~km}$. Turkistan consists of 13 districts and 3 cities of regional subordination. Turkistan region was founded on March 10, 1932 as the South Kazak region, the name of which was changed to South Kazakhstan in 1936. From May 3, 1962 to July 6, 1992, the region was called Shymkent, and in 1992 the name of the region was returned to South Kazakhstan. On June 19, 2018, by the decree of the President of Kazakhstan, the South Kazakhstan region was renamed into Turkistan, and its administrative center was moved from Shymkent to Turkistan; Shymkent was removed from the South Kazakhstan region, having received the status of a city of republican significance (a separate administrative-territorial unit, equal to the region). The authors include 2 factories as research objects which are located in Shymkent - phosphorus factory and lead factory. 
At present, the major source of soil contamination in the Turkistan region is the Shymkent lead factory, which annually emits 677.7 tons of lead, 1.660 tons of other heavy metals, 18.000 tons of sulfur dioxide, 21.000 tons of carbon dioxide, and 0.47 tons of chemical substances [33-35].

The landscape of southern Kazakhstan has some diversity: its plains are broken by lowlands and mountains of varying heights, and sandy areas are present. The diversity of landscape patterns not only affects the climate but also affects the soil environment. For instance, plain soils and mountain soils both can be found in the southern part of the country. At the same time, a substantial portion of the southern Kazakhstan is desert with very small air humidity $(0.1$ to 0.05$)$ and $80-150 \mathrm{~mm}$ of rainfall per year $[36,37]$.

\section{Soil Sampling and Analysis}

Soil samples were taken at different locations in the city of Shymkent and Turkistan region: around industrial sites (phosphorus, cement, and lead factories), around polymetal factories on Achysai and Baizhansai, along Kentau transform factory. Sources of pollution as well as the presence of erosion were determined through reconnaissance survey, the preliminary examination of the region.

The soil sampling was performed according to ISO 10381 and GOST, the Russian state standard for soil sampling [27-32]. Samples were collected from different soil layers and the morphogenetic properties of soils were determined.

The soil tests were run by different procedures. The humus level was determined according to Tyurin [38]. The content of nitrogen was measured by the Kjeldahl method [39]. The content of phosphorus was assessed using the Ginsburg and Shcheglova methods [40]. The total potassium content of soil was evaluated using Smith method [41]. The hydrolyzable nitrogen content was determined with the help of the Tyurin-Kononova method [38]. The content of mobile phosphorus was assessed by the Machigin method [42]. The content of mobile potassium was assessed using modified Grabarov method [43]. For $\mathrm{pH}$ measurement, the potentiometric method was used [43]. The absorbed bases ( $\mathrm{Ca}$ and $\mathrm{Mg}$ ) were determined by the trilonometric method [43]. Granulometric composition was determined by pipette method using pyrophosphate method of probe preparation (modified by Grabarov) and micro aggregate analysis by Kachinskiy [43]. The specific gravity of soil was determined by using a pycnometer and the bulk density of the soil specimen was determined with the help of a cylindrical drill $\left(50 \mathrm{~m}^{3}\right)$ by Kachinsky [43].

Samples were tested for qualitative content on atomic absorption spectrometry at IRLIP laboratory. According to the amount of absorption, the authors found a ratio between absorption and concentration of elements; thus, elements with high absorption were highlighted.

The contents of heavy metals were evaluated by scanning electron microscopy using a JSM-6460LV scanning electron microscope (Jeol, Japan).

\section{Results and Discussion}

The results of heavy metal soil tests for different areas are depicted in Table 1 and Figs 1-6. As can be seen by the data below, the amounts of elements such as $\mathrm{Na}, \mathrm{Al}, \mathrm{Si}, \mathrm{P}, \mathrm{S}, \mathrm{Ti}, \mathrm{C}, \mathrm{O}, \mathrm{Mg}, \mathrm{Ca}$, and Fe were below the level of concern.

According to data in Table 1, some elements (Al, Si, P, S, and Ti) were found in concentrations lower than the permissible levels $(p \leq 0.05$, in all cases $10 x$ repetition). The only exception is the sample of soil from the phosphorus factory where the content of phosphorus was found to be beyond the guideline value $(p \geq 0.05)$. The low quantity of silicon in soil leads to the emergence of $\mathrm{Si}$ deficiency symptoms in cultivated plants, such as the weak root system, small leaf size, late blossoming, low resistance to adverse environmental factors, and poor yields. This deficiency of micronutrients (Table 1) suggests that areas under investigation have soils with decreased fertility and the elevated level of phosphorus around the phosphorus factory indicates the presence of soil contamination.

Table 1 . The contents of heavy metals in the examined soil specimens.

\begin{tabular}{|c|c|c|c|c|c|c|}
\hline Sampling site & $\mathrm{Al}$ & $\mathrm{Si}$ & $\mathrm{P}$ & $\mathrm{Zn}$ & $\mathrm{Pb}$ & $\mathrm{Ti}$ \\
\hline Cement factory & 3.39 & 12.33 & 0.08 & 0.35 & 0.14 & 0.23 \\
\hline Lead factory & 3.16 & 11.75 & 0.10 & 14 & 37 & 0.26 \\
\hline Achisai Polymetallic Combine & 4.94 & 18.39 & & 24.01 & 0.74 & 0.33 \\
\hline Bayzhansayskoe deposits of ores & 5.07 & 16.5 & 0.06 & 22.94 & 3.02 & 0.34 \\
\hline Kentau transformer factory & 6.65 & 24.24 & & 2.96 & 2.84 & 0.46 \\
\hline Phosphorus factory & 5.06 & 16.28 & 1.25 & 1.41 & 0.41 & 0.31 \\
\hline Permissible concentration & - & - & - & 23 & 32.0 & - \\
\hline
\end{tabular}




\section{Cement factory (Tassai)}
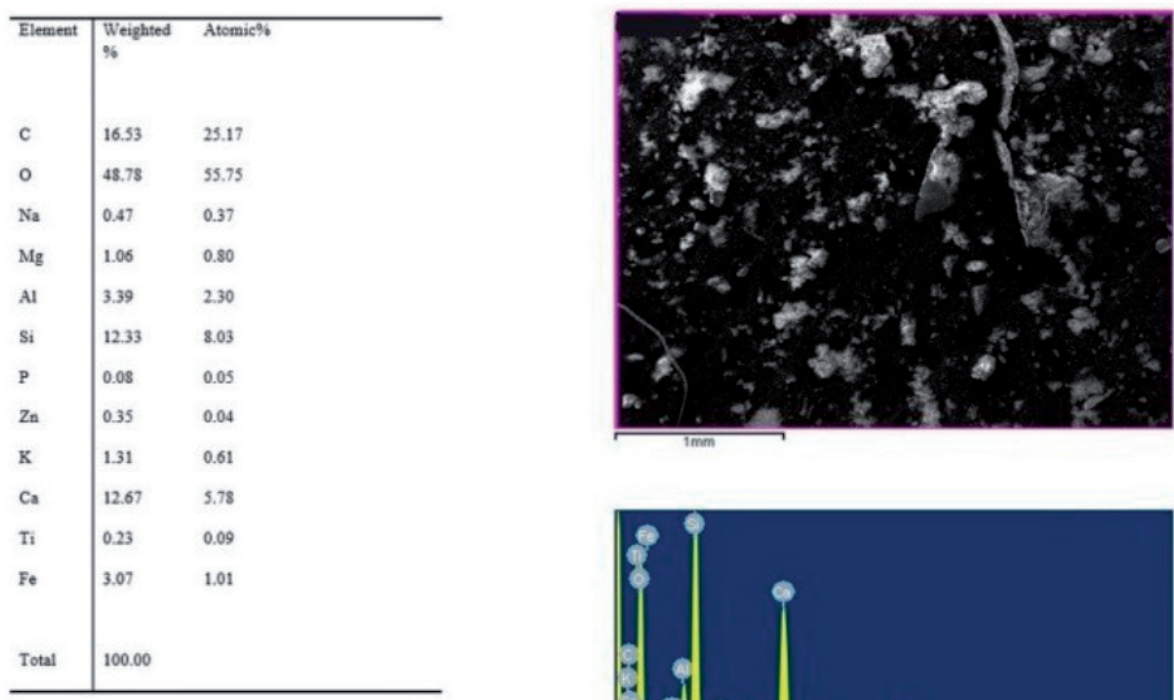

Notes:

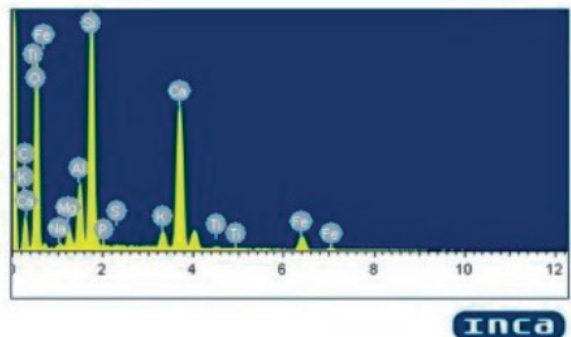

Fig. 1. SEM and EDAX images of the examined metals in soil samples from the area around the cement factory, Tassai.

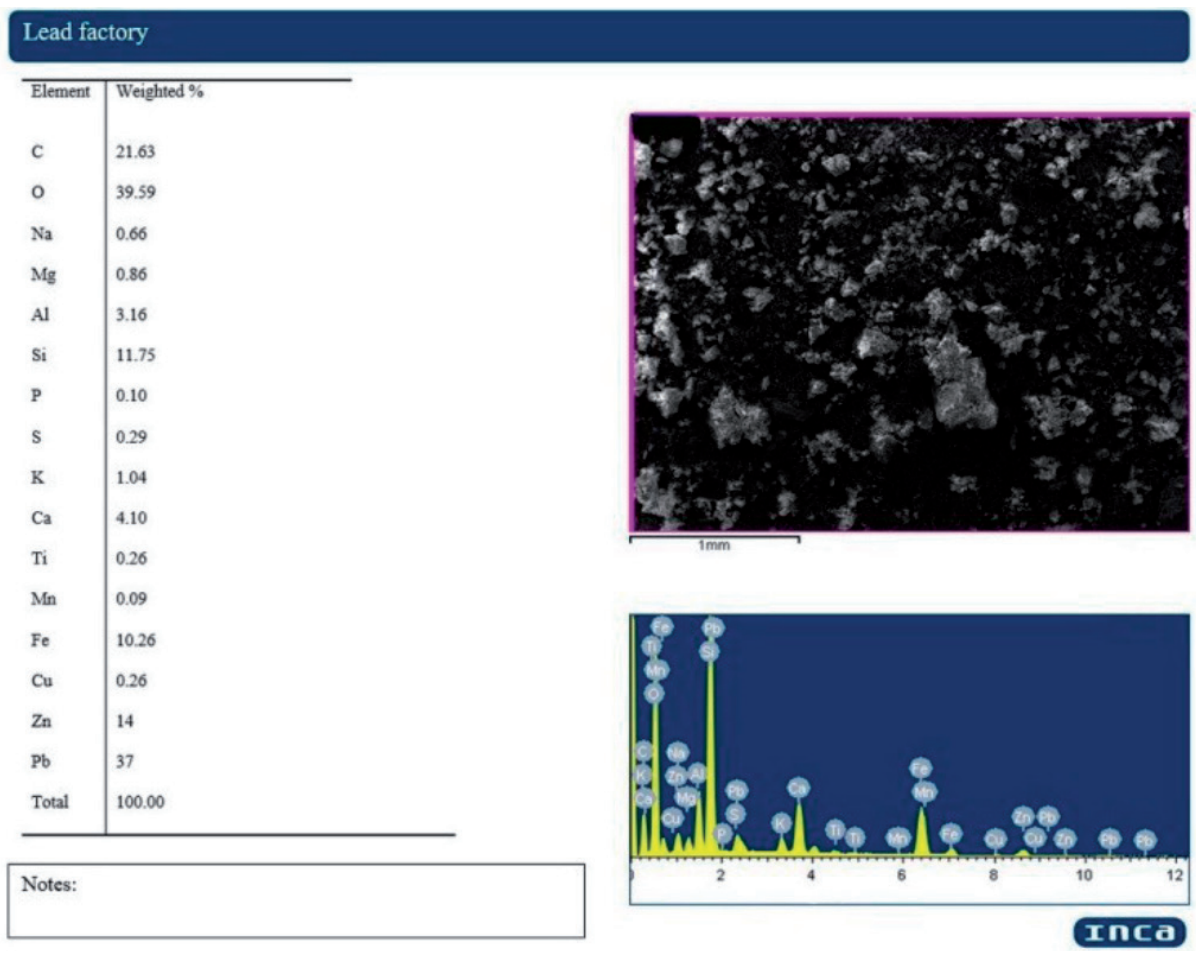

Fig. 2. SEM and EDAX images of the examined metals in soil samples from the area around the lead factory.

According to data in Figs 4-6, 4 out of 5 areas under investigation were contaminated with elevated amounts of metals such as $\mathrm{Na}, \mathrm{Mg}, \mathrm{K}$, and $\mathrm{Ca}$. In particular, the content of sodium $(\mathrm{Na})$ around the lead and phosphorus factories, as well as along the highway corridor (lead factory) was higher than the permissible level $(\mathrm{p} \leq 0.05)$. The contents of $\mathrm{Na}$ in soils around the cement factory were found to be lower than the permissible level $(p \leq 0.05)$. The elevated concentration of mobile sodium in soil can disrupt its physical and chemical composition. 


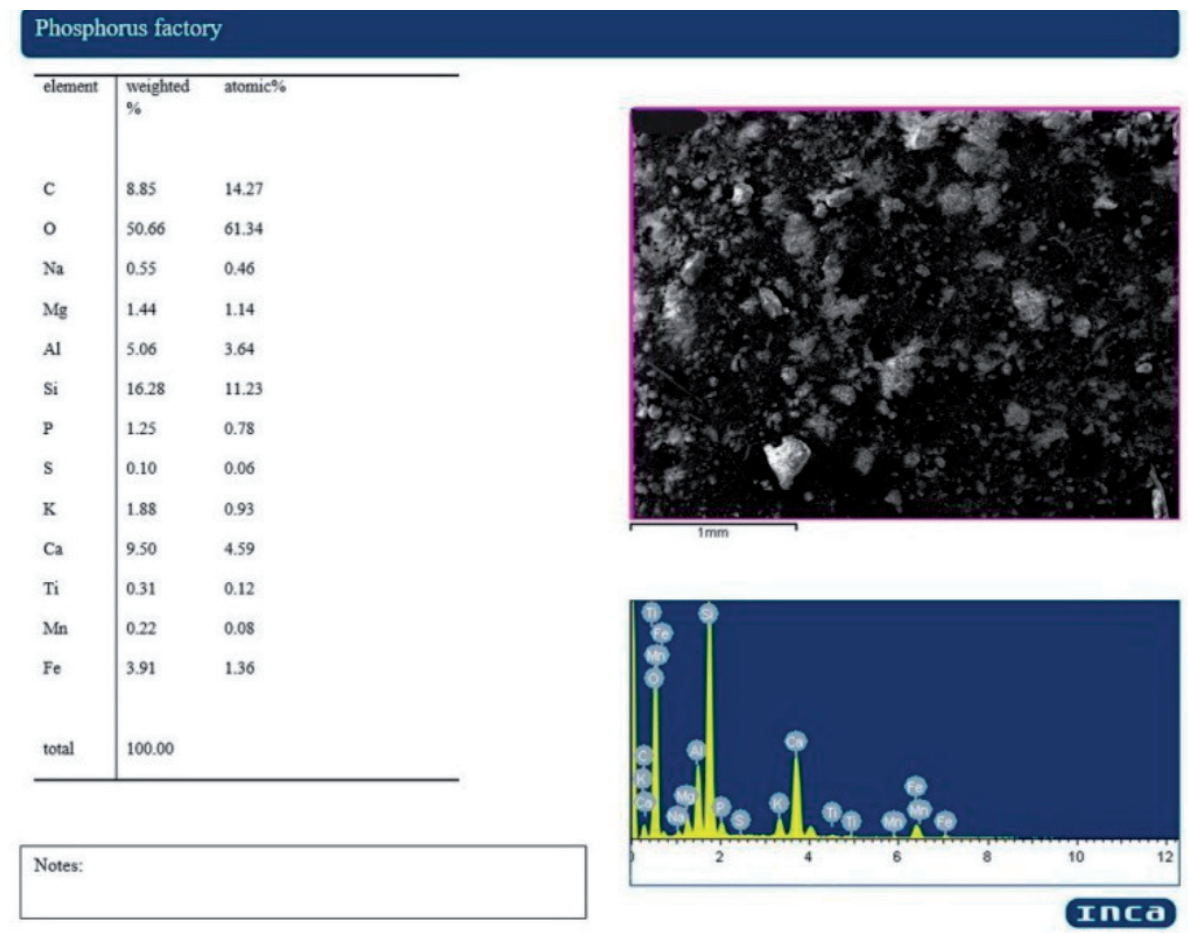

Fig. 3. SEM and EDAX images of the examined metals in soil samples from the area around the phosphorus factory.

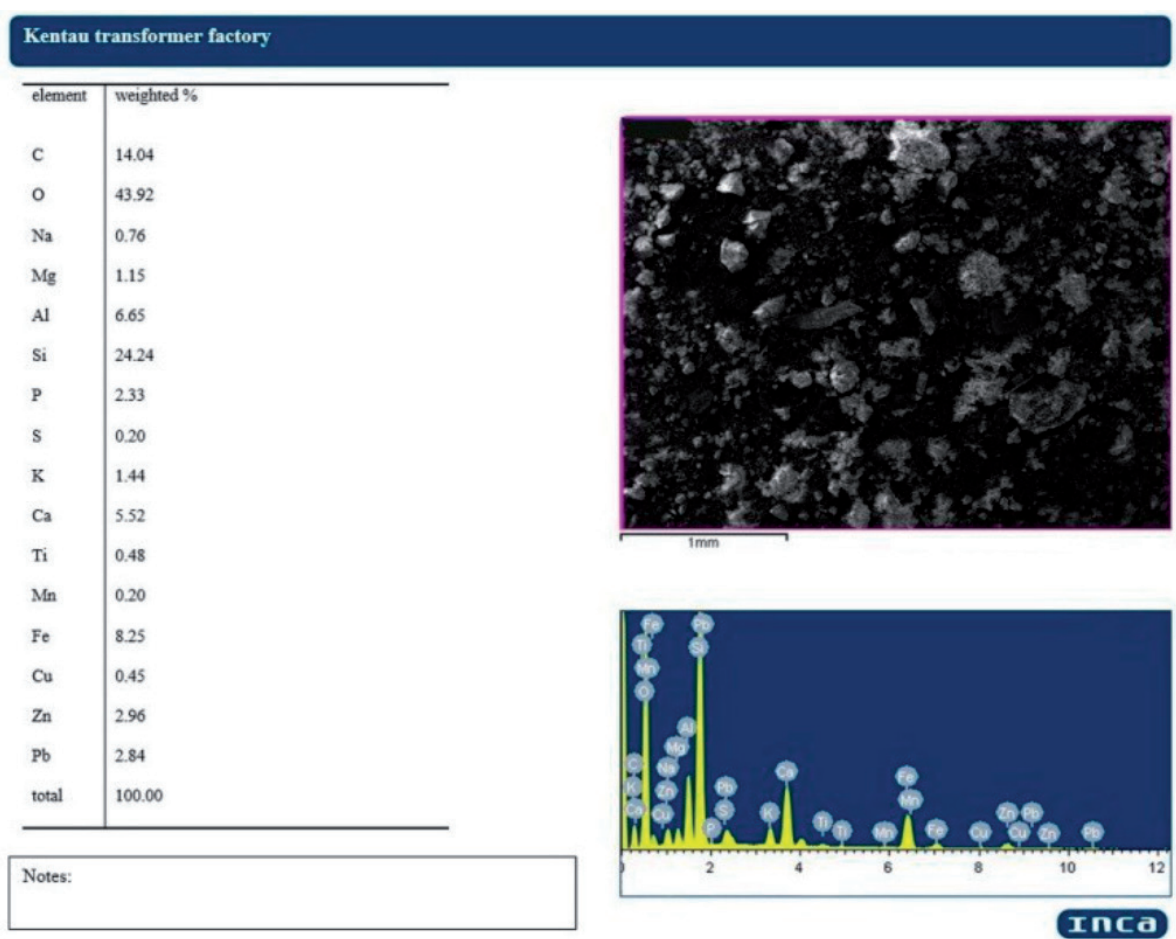

Fig. 4. SEM and EDAX images of the examined metals in soil samples from the area around the Kentau transformer factory.

$\mathrm{Mg}$ concentrations obtained from each soil sample collected exceeded the threshold of $0.63 \% \quad(\mathrm{p} \leq 0.05)$. A decline in magnesium along with the reduction of organic content in soil can enhance its negative properties. The highest Mg concentration was discovered in soil samples from areas around the lead factory $(\mathrm{p} \leq 0.05)$. This elevation in $\mathrm{Mg}$ may be associated with the practice of bismuth extraction, which is performed using magnesium and calcium. Ca concentrations were found to be higher than the $1.37 \%$ threshold in all the soil samples under study $(\mathrm{p} \leq 0.05)$. As expected, the highest $\mathrm{Ca}$ concentrations were found in soil samples from areas around the cement factory. Since calcium is commonly used in the manufacture of cement, 


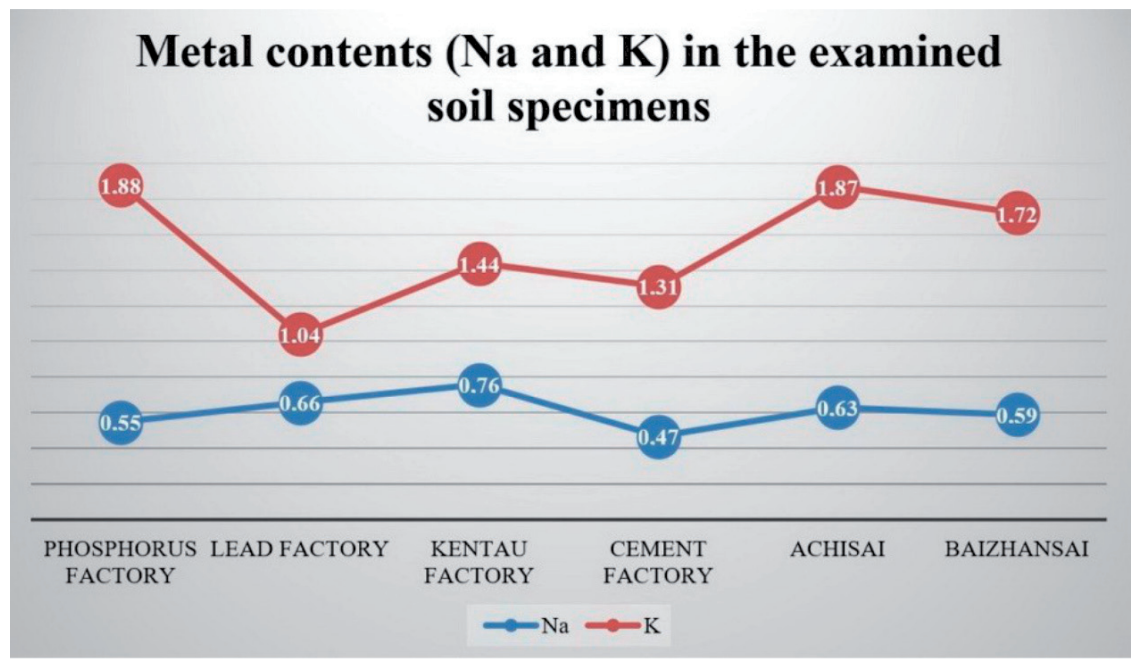

Fig. 5. Metal contents ( $\mathrm{Na}$ and $\mathrm{K})$ in the examined soil specimens.

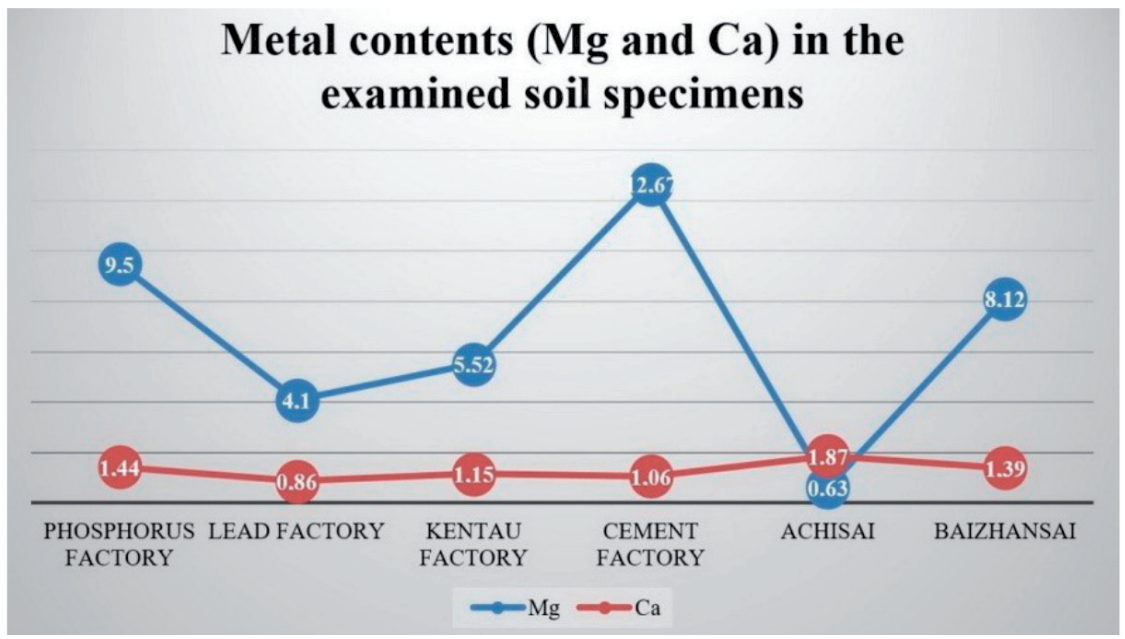

Fig. 6. Metal contents ( $\mathrm{Mg}$ and $\mathrm{Ca})$ in the examined soil specimens.

its concentrations around the cement-manufacturing units is often elevated. The high content of $\mathrm{Ca}$ also was found in soil samples from the lead factory $(\mathrm{p} \leq 0.05)$. Too much calcium in the soil may result in chlorosis and the depletion of boron. Excess calcium also inhibits the uptake of trace elements by plants. In general, the optimal ratio of calcium to magnesium should be $5: 1$ to enhance the growth of plants, yet it was found to be below this level.

The analysis of soil specimens from industrial sites and the highway roadside suggests that the said territories experience a decrease in soil fertility. Among all tested specimens, samples from the territory around the phosphorus factory had the highest contents of aluminum, silicon, phosphorus, sulfur, and potassium. At the same time, these samples contained the least amount of calcium. These findings may be useful in preventing and reducing the heavy metal soil pollution.

Although only topsoil from a depth of $0 \sim 20 \mathrm{~cm}$ was collected in this study, while samples were collected from 0 to 5 or 0 to $10 \mathrm{~cm}$ and from areas with different land uses in other studies, the relatively lower concentrations of heavy metals in the soils in Kentau could be the result of a shorter accumulation time and lower rate. Certainly, the deeper sampling depth of this study may also influence the concentration levels. Compared to average concentrations in urban soils, phosphorus concentrations in topsoil samples near phosphorus factories are slightly lower but are comparable to those measured in other parts of the world, except for Shenzhen. The concentrations of Ti in the analyzed samples are also generally lower than those reported in studies of metropolitan areas in some big cities, such as Chengdu, Central Jordan and Sicily, and are comparable to those measured in some other parts of the world.

In the past 5 years, there has been a great deal of interest in soil contamination by heavy metals caused by industrial operations. For example, Zhang et al. [44] assessed the impact of coal mining on the spatial 
distribution of potentially toxic metals in arable farmlands across the Shandong Province, China. The results showed that the concentration of the tested toxic metals declined to the following order: $\mathrm{Cd}, \mathrm{Ni}, \mathrm{Cr}, \mathrm{Zn}$, $\mathrm{Cu}$, and $\mathrm{Pb}$. Jiang et al. [45] looked at the concentrations of metals ( $\mathrm{Hg}, \mathrm{As}, \mathrm{Ni}, \mathrm{Pb}, \mathrm{Cd}, \mathrm{Cr}, \mathrm{Cu}$, and $\mathrm{Zn}$ ) in soil, groundwater, air, and plants (wheat and maize) cultivated in a village located near a battery factory in Xinxiang (Henan Province, China). The authors found that some metals $(\mathrm{Cd}, \mathrm{Ni}$, and $\mathrm{As})$ came from industrial sources, such as wastewater for irrigation and sludge generated from battery industry, whilst other metals $(\mathrm{Pb}$ and $\mathrm{Cr}$ ) originated from agricultural sources. Chen et al. [46] collected 90 soil samples from varying depths $(0-20,20-40,40-60 \mathrm{~cm})$ and 120 gridded plant samples from coal waste reclamation areas in Huainan, China, to investigate the concentrations and distribution features of toxic elements in soils and plants.

Previous studies of soil revealed high concentrations of lead $(1800 \mathrm{mg} / \mathrm{kg})$, zinc $(410 \mathrm{mg} / \mathrm{kg})$, cadmium (93 $\mathrm{mg} / \mathrm{kg})$, and copper (62 $\mathrm{mg} / \mathrm{kg})$ [47, 48]. The studies conducted $1.5 \mathrm{~km}$ away from the Shymkent lead factory found out that soils exposed to industrial waste (oils, dyes, petroleum products, phosphates, lead, arsenic, etc.) discharged by the factory contained 40 times more cadmium than it was considered acceptable [3]. According to field measurements [49, 50], soil contaminants such as sulfur dioxide and other sulfur compounds are often accompanied by released gases and fine particles, such as ash, limestone dust, and heavy metal particles from industrial plants.

Among the many problems currently facing humanity, one of the first places is occupied by the problem of environmental pollution by various chemical substances - products of technogenesis, most of which accumulate in the soil. Heavy metals occupy a significant place among the pollutants. The main factor in the severity of this environmental situation remains the high concentration of nature-polluting and nature-destroying industries. Ferrous and non-ferrous metallurgy, chemical and mining industries, mechanical engineering and others are dominant environmentally hazardous industries. Anthropogenic soils differ from natural soils in chemical and water-physical properties. They are mixed with construction waste, household waste, which is why they have a higher alkalinity than their natural counterparts. The main part of pollutants enters urban soils with atmospheric precipitation, from places of industrial and domestic waste. Particularly dangerous is soil pollution with heavy metals. To assess the content of heavy metals (copper, nickel, zinc, lead) in natural and anthropogenic soils of the Turkistan region, the content was measured using a scanning electron microscope. This method can be described as follows. The electrons of the probe (beam) interact with the sample material and generate various types of signals: secondary electrons, back-reflected electrons, Auger electrons, X-rays, light radiation (cathodoluminescence), etc. These signals are carriers of information about the topography and material of the sample. From the measurement results, it can be seen that the highest content of heavy metals in the soil is observed directly near the source of pollution. The uneven distribution occurs due to the different intensity of the anthropogenic factor in the places of measurements. It is in the cities and the territories closest to them that industrial production and agricultural zones are concentrated. The most obvious pollution is found in the anthropogenic soils of Ashysai, Baizhansai and the Lead Plant in Shymkent, which is associated with the developed industry in these areas, intensive agriculture and an extensive developed network of roads.

Thus, according to the present research, there is a noticeably increased content of heavy metals in the soil in many areas of the Turkistan region. However, a significant excess of permissible standards is observed in close proximity to large industrial enterprises, based on which it can be concluded that the pollution is narrowly localized. Basically, on the territory of the Turkistan region, the content of heavy metals in the soil is within the normal range. However, according to forecasts, taking into account the constant growth of the industry and the increase in road congestion, the situation may change for the worse.

\section{Conclusions}

It was found that $\mathrm{Mg}$ concentrations in each collected soil sample exceeded the threshold value by $0.63 \%$ $(p \leq 0.05)$. The maximum $\mathrm{Mg}$ concentration was found in soil samples from areas near the lead plant $(\mathrm{p} \leq 0.05)$. $\mathrm{Ca}$ concentrations above the threshold value of $1.37 \%$ were observed in all soil samples studied $(p \leq 0.05)$ near the cement plant, as well as in soil samples from the lead plant $(\mathrm{p} \leq 0.05)$.

This study presents the results of soil contamination tests conducted in the Turkistan region and Shymkent. Some metals ( $\mathrm{Na}, \mathrm{Mg}, \mathrm{K}$, and $\mathrm{Ca}$ ) were found to be elevated in samples taken at 6 sampling sites. Namely, the elevated concentrations of $\mathrm{Na}$ were detected in samples collected around the lead and phosphorus factories and along the highway corridor. The highest concentrations of $\mathrm{Mg}$ were found in the samples from the lead factory. The highest $\mathrm{Ca}$ concentrations were detected in samples taken near the cement factory. Some metals (Al, Si, P, S, and Ti) were found to be lower that the recommended thresholds. Among other things, this poses a risk of declining yields. Samples from the territory around the phosphorus factory were higher in $\mathrm{Al}, \mathrm{Si}, \mathrm{P}, \mathrm{S}$, and $\mathrm{K}$ when compared to samples from other sites.

The principle of operation of the SEM Jeol has been studied. An increased content of heavy metals (copper, zinc, lead) was revealed in the soil samples of Ashysai, Baizhansai and the former lead plant in the city of Shymkent, which is associated with the location of large industrial enterprises in these areas. 
Based on the cartogram of soil contamination with heavy metals in the Turkistan region, Ashchysai, Kentau, Phosphorus plant belong to the zone of medium pollution, and the lead plant and Baizhansai belong to the zone of high pollution.

\section{Acknowledgments}

This research did not receive any specific grant from funding agencies in the public, commercial, or not-forprofit sectors.

\section{Conflict of Interest}

The authors declare no conflict of interest.

\section{References}

1. YUAN L., ZHI W., LIU Y., KARYALA S., VIKESLAND P.J., CHEN X., ZHANG H. Lead toxicity to the performance, viability, and community composition of activated sludge microorganisms. Environ. Sci. Technol. 49 (2), 824, 2015.

2. TAGHIPOUR H., MOSAFERI M., ARMANFAR F., GAEMMAGAMI S.J. Heavy metals pollution in the soils of suburban areas in big cities: a case study. Int. J. Environ. Sci. Technol. 10 (2), 243, 2013.

3. LI X., POON C.S., LIU P.S. Heavy metal contamination of urban soils and street dusts in Hong Kong. Appl. Geochem. 16 (11-12), 1361, 2001.

4. ARIVALAGAN P., SINGARAJ D., HARIDASS V., KALIANNAN T. Removal of cadmium from aqueous solution by batch studies using Bacillus cereus. Ecol. Eng. 71, 728, 2014.

5. TAIWO A.M., GBADEBO A.M., OYEDEPO J.A. OJEKUNLE Z.O., ALO O.M., OYENIRAN A.A.; ONALAJA O.J., OGUNJIMI D., TAIWO O.T. Bioremediation of industrially contaminated soil using compost and plant technology. J. Hazard. Mater. 304, 166, 2016.

6. DHANARANI S., VISWANATHAN E., PIRUTHIVIRAJ P., ARIVALAGAN P., KALIANNAN T. Comparative study on the biosorption of aluminum by free and immobilized cells of Bacillus safensis KTSMBNL 26 isolated from explosive contaminated soil. J. Taiwan Inst. Chem. Eng. 69, 61, 2016.

7. KARTHIK C., BARATHI S., PUGAZHENDHI A., RAMKUMAR V.S., THI N.B.D., ARULSELVI, P.I. Evaluation of $\mathrm{Cr}(\mathrm{VI})$ reduction mechanism and removal by Cellulosimicrobium funkei strain AR8, a novel haloalkaliphilic bacterium. J. Hazard. Mater. 333, 42, 2017.

8. ULLAH A., HENG S., MUNIS M.F.H., FAHAD S., YANG X. Phytoremediation of heavy metals assisted by plant growth promoting (PGP) bacteria: a review. Environ. Exp. Bot. 117, 28, 2015.

9. CHEN M., XU P., ZENG G., YANG C., HUANG D., ZHANG J. Bioremediation of soils contaminated with polycyclic aromatic hydrocarbons, petroleum, pesticides, chlorophenols and heavy metals by composting: applications, microbes and future research needs. Biotechnol. Adv. 33 (6), 745, 2015.
10. ZERAATKAR A.K., AHMADZADEH H., TALEBI A.F., MOHEIMANI N.R., MCHENRY M.P. Potential use of algae for heavy metal bioremediation, a critical review. J. Environ. Manage. 181, 817, 2016.

11. KARTHIK C., OVES M., THANGABALU R., SHARMA R., SANTHOSH S.B., ARULSELVI P.I. Cellulosimicrobium funkei-like enhances the growth of Phaseolus vulgaris by modulating oxidative damage under Chromium (VI) toxicity. J. Adv. Res. 7 (6), 839, 2016.

12. KHAN M.S., ZAIDI A., WANI P.A., OVES M. Role of plant growth promoting rhizobacteria in the remediation of metal contaminated soils. Environ. Chem. Lett. 7 (1), 1, 2009.

13. BANFALVI G. Cellular Effects of Heavy Metals; Springer: Dordrecht, 2011.

14. WYSZKOWSKA J., BOROWIK A., KUCHARSKI M., KUCHARSKI J. Effect of cadmium, copper and zinc on plants, soil microorganisms and soil enzymes. J. Elem. 18 (4), 769, 2013.

15. SOBOL Z., SCHIESTL R.H. Intracellular and extracellular factors influencing $\mathrm{Cr}$ (VI and $\mathrm{Cr}$ (III) genotoxicity. Environm. Mol. Mutagen. 53 (2), 94, 2012.

16. GUNDACKER C., GENCIK M., HENGSTSCHLÄGER $\mathrm{M}$. The relevance of the individual genetic background for the toxicokinetics of two significant neurodevelopmental toxicants: mercury and lead. Mutat. Res. Rev. Mutat. Res. 705 (2), 130, 2010.

17. RAIS. The Risk Assessment Information System. Available online: https://rais.ornl.gov/ (accessed on 17 March 2021).

18. ADAMIEC E., JAROSZ-KRZEMIŃSKA E., WIESZAŁA R. Heavy metals from non-exhaust vehicle emissions in urban and motorway road dusts. Environ. Monit. Assess. 188 (6), 369, 2016.

19. CAI L.M., WANG Q.S., WEN H.H., LUO J., WANG S. Heavy metals in agricultural soils from a typical township in Guangdong Province, China: Occurrences and spatial distribution. Ecotox. Environ. Safety 168, 184, 2019.

20. XIA X., CHEN X., LIU R., LIU H. Heavy metals in urban soils with various types of land use in Beijing, China. J. Hazard. Mater. 186 (2-3), 2043, 2011.

21. GOWD S.S., REDDY M.R., GOVIL P.K. Assessment of heavy metal contamination in soils at Jajmau (Kanpur) and Unnao industrial areas of the Ganga Plain, Uttar Pradesh, India. J. Hazard. Mater. 174 (1), 113, 2010.

22. SAGHATELYAN A.K., AREVSHATYAN S.H., SAHAKYAN L.V. Ecological-geochemical assessment of heavy metal pollution of the territory of Yerevan. Electronic Journal of NAS RA 1 (1), 36, 2003.

23. TOMLINSON D.L., WILSON J.G., HARRIS C.R., JEFFREY D.W. Problems in the assessment of heavymetal levels in estuaries and the formation of a pollution index. Helgoländer Meeresun 33 (1), 566, 1980.

24. WU S., PENG S., ZHANG X., WU D., LUO W., ZHANG T., ZHOU S., YANG G., WAN H., WU L. Levels and health risk assessments of heavy metals in urban soils in Dongguan, China. J. Geochem. Explor. 148, 71, 2015.

25. GOST 26107-84 Soils. GOST 26107-84 Soils. Methods for the determination of total nitrogen, 1985. Available online: http://docs.cntd.ru/document/gost-26107-84 (accessed on 17 March 2021).

26. GOST 26213-84 Soils. GOST 26213-84 Soils. Determination of humus by the Tyurin method as modified by SRIAS, 1985. Available online: http://www.normacs. com/doc/d1091649/ (accessed on 17 March 2021). 
27. GOST 26261-84 Soils. GOST 26261-84 Soils. Methods for the determination of gross phosphorus, and gross potassium, 1985. Available online: http://docs.cntd.ru/ document/1200023483 (accessed on 17 March 2021).

28. GOST 26427-85 Soils. GOST 26427-85 Soils. Method for the determination of sodium and potassium in an aqueous extract, 1986. Available online: http://docs.cntd. $\mathrm{ru} /$ document/1200023488 (accessed on 17 March 2021).

29. GOST 26428-85 Soils. GOST 26428-85 Soils. Methods for the determination of calcium and magnesium in an aqueous extract, 1986. Available online: http://docs.cntd. $\mathrm{ru} /$ document/gost-26428-85 (accessed on 17 March 2021).

30. GOST 26487-85 Soils. GOST 26487-85 Soils. Determination of exchangeable calcium and exchangeable (mobile) magnesium by SRIAS methods (with amendment), 1986. Available online: http://docs.cntd.ru/document/gost26487-85 (accessed on 17 March 2021).

31. GOST 26950-86 Soils. GOST 26950-86 Soils. Method for determination of exchangeable sodium, 1987. Available online: http://docs.cntd.ru/document/gost-26950-86 (accessed on 17 March 2021).

32. GOST 50683-94 Soils. GOST 50683-94 Soils. Determination of mobile compounds of copper and cobalt by the method of Krupskiy and Aleksandrova as modified by SRIAS, 1995. Available online: http://docs.cntd.ru/ document/gost-r-50683-94 (accessed on 17 March 2021).

33. EMAMVERDIAN A., DING Y., MOKHBERDORAN F., XIE Y. Heavy metal stress and some mechanisms of plant defense response. Sci. World J. 2015, e756120, 2015.

34. KOZYBAEVA F.E., BEISEEVA G.B., SAPAROV G.A. The content of heavy metals in soils on the territory of zinc, lead plants and tailings. In III International Scientific and Practical Conference "Modern Methodology of Science and Education"; Dubai, UAE, pp. 5-10, 2017.

35. KAZHYDROMET. Branch of RSE "Kazhydromet" in the Turkistan region. Available online: https:/www. kazhydromet.kz/ru/branches (accessed on 17 March 2021).

36. GERGOCS V., HUFNAGEL L. Application of Oribatid mits as indicators (review). Appl. Ecol. Environ. Res. 7 (1), 79, 2009.

37. HOFFMANN G. Verteilung und Herkunft einiger Enzyme im Boden. Z. Pflanzenernähr. Düng. Bodenkd. 85 (2), 97, 1959.
38. TYURIN I.V. Organic matter of soils and its role in soil formation and fertility. Doctrine of Soil Humus; Selkhozgiz: Moscow, 1937.

39. KJELDAHL J. Neue Methode zur Bestimmung des Stickstoffs in organischen Körpern. Zeitschrift für analytische Chemie 22 (1), 366-383, 1883.

40. GINZBURG K.E., SHCHEGLOVA G.M. Determination of nitrogen, phosphorus and potassium in plant material from one sample. Pochvovedenie 5, 1, 1960.

41. SMITH S.J., SCOTT A.D. Extractable potassium in grundite illite: I. Method of extraction. Soil Sci. 102 (2), $115,1966$.

42. GOST 26204-91 Soils. GOST 26204-91 Soils. Determination of mobile compounds of phosphorus and potassium by Chirikov method in modification of CINAO, 1993. Available online: https:/docs.cntd.ru/ document/1200023447 (accessed on 17 March 2021)

43. SOKOLOV A.V. Agrochemical methods of soil research; Science: Moscow, 1975.

44. ZHANG K., QIANG C., LIU J. Spatial distribution characteristics of heavy metals in the soil of coal chemical industrial areas. J. Soil. Sediment. 18 (5), 2044, 2018.

45. JIANG H.H., CAI L.M., WEN H.H., HU G.C., CHEN L.G., LUO J. An integrated approach to quantifying ecological and human health risks from different sources of soil heavy metals. Sci. Total Environ. 701, 134466, 2020.

46. CHEN H., TENG Y., LU S., WANG Y., WU J., WANG J. Source apportionment and health risk assessment of trace metals in surface soils of Beijing metropolitan, China. Chemosphere 144, 1002, 2016.

47. LEHMANN J., JOSEPH S. Biochar for Environmental Management; Earthscan: Oxford, UK, 2009.

48. SOLHØY I.W., SOLHØY T. The fossil oribatid mite fauna (Acari: Oribatida) in late-glacial and earlyHolocene sediments in Kråkenes Lake, western Norway. J. Paleolimnol. 23 (1), 35, 2000.

49. CONVEY P., BLOCK W., PEAT H.J. Soil arthropods as indicators of water stress in Antarctic terrestrial habitats? Glob. Change Biol. 9 (12), 1718, 2003.

50. HEMIDA S.K., OMAR S.A., ABDEL-MALLEK A.Y. Microbial populations and enzyme activity in soil treated with heavy metals. Water Air Soil Pollut. 95 (1-4), 13, 1997. 